\title{
A Discussion on Conception of World History Based on the Perspective of Wu Yujin
}

\author{
Hui Li \\ College of Political Science and Law, Yulin University, Yulin, 719000, China
}

Keywords: Wu Yujin. World history. World history discipline

\begin{abstract}
Wu Yujin is the founder of world history discipline in China.Strictly speaking,before the establishment of the new China ,China didn't have a discipline called world history.It was not until the establishment of new China,world history ,as a discipline appeared in China on the basis of Mr. Wu Yujin's theory of macrocosm .Before that,the main content of historiography courses in our country is western history. This year is Mr. Wu's 101 birthday and I carried out a series of discussion about the conception of world history on the basis of Mr. Wu's theory of macrocosm.
\end{abstract}

\section{An Introduction to the World History Discipline}

$\mathrm{Mr} \mathrm{Wu}$ thinks that the world history is a specific discipline separated from history and its main content is a series of exploration to the process of the development of human civilization.Just as what the great tutor Marx said:"the world does not always exist and the world history is a result of history."During the process of the development of human civilization, the lifestyle of people from various nations has gradually changed from a close condition to a continuously open one. As a result, features of labor division of various nations are disappearing and the trend of becoming a world history is increasingly obvious.

What I must point out here is that the world history is not just a simple mix of the history of all countries, nations and areas. Mr Wu pointed out that world history should be a systemic concept. World history is a branch of social sciences, and its exploring aim requires historical studies on our country and other areas from various aspects. But it doesn't simply refer to a history of outside China, but a study to the history of world civilization at a profounder level. In terms of the real situation, it is not practical to collect and sort all history from all areas. Even the job is done, it is just a pile of accumulation of historical data. And you could not see the development process and general view of world history, just like what we usually said:"The endless attention to trees at the expense of forests", resulting in a not scientific and systemic cognition of world history.

From the statement above, we can find out that Mr Wu's conception of world history is a microscopical view, which he stressed himself. He thinks that the world is macroscopical, and one of its most outstanding characteristics is the openness of view, which will digest the contents of country history and area history and accomplish the coordination and integration of the three. Thus, the overall situation and the trend of different historical periods can be stated clearly. Although world history absorbs contents of country history and area history to some extent, it also supplements the inadequacy of country history and area history. So, world history is not a simple addition, but a surpassing of country history and area history.

\section{The Bidirectional Development of World History}

According to Mr. Wu's study of world history, the world is not only a process of horizontal development, but also a process of depth development and an in-depth study was conducted on it. During the process that history is continuously developing toward the world history direction, its horizontal development and depth development don't proceed simultaneously or become two individuals, but affect and restrain each other. The association between horizontal development and depth development is a process which is accelerating and strengthening. At first, the speed of fusion is quite slow and it didn't properly affect the overall development of world history. Till later on, the 
association between horizontal development and depth development is increasingly close which transformed world history from scattered history into an organic whole.

When horizontal development and longitudinal development are promoting each other, the stage and depth which world history's longitudinal development reached have great influence on its horizontal development's breadth and width. However, when its longitudinal development restrains its horizontal development, it also receives the adverse effect from it. If its horizontal development can adapt its longitudinal development to some extent; it will promote and deepen its longitudinal development. When human history entered into the capitalist era, this counterforce is most obvious.

Actually and fundamentally speaking, horizontal development and longitudinal development are just two aspects of the development of world history, they both establish on the basis of the continuous development of material civilization and both promote the development of material civilization. According to studies of world history by scholars from various countries, they all emphasizes on horizontal development of world history and provide a lot of research results of great value. But to some extent, they ignore the longitudinal study, which is a new aspect of world history study. So far, we should know that the development of world history is a bi-directional process and the two developments interact and promote each other. So when we conduct a research on world history, we should pay attention to both aspects without bias.

\section{The Monographic Study Of World History}

During the process that history develops into world history, there are a lot of contents which belong to neither country history nor area history. We defined this kind of content as specific history. The study on specific history is also an important content of world history. If this part of history is ignored, world history cannot be integrated and an overall research of world history cannot become true. For this kind of history, Mr. Wu divided it into three categories. The first type refers that during a fixed historical period, investigate history in different areas in a comprehensive way, so as to have a overall understanding of world history at this time. The second type is to investigate the relationship between a specific area and world history. The third type refers some significant historical movements, such as the French revolution, two world wars and the industrial revolution. Similar events had happened in numerous countries.

Under the guidance of Mr. Wu's theory of macrocosm, the mainline of world history development during a specific period can be clearly represented by a comprehensive analysis to this common phenomenon. Mr. Wu stated the importance of the monographic study in theory and researched some special topics of world history in person, such as, The Agriculture-Oriented and Mercantilism In World History, The Agricultural World Brewed The Industrial World In History, The Nomadic World And Agricultural World In History. These three articles are not only rich in material, but also penetrating. It deeply analyzed every significant movement of the long journey of human history becoming world history and it can be called as a great project.

\section{A Thinking Of The World History Discipline In China}

After Mr. Wu Yujin studied the staging of world history, he started to think deeply about the thoughts of Chinese world history and the discipline system of world history. In 1964, the publication of Age And World History is a banner of conducting a thinking of world history and the discipline system of world in China after the publishing of World History. He thinks that the conception of world history in Soviet Union has a profound effect on that of our country and conducted a series of summary on the previous research results according to his practical work done before of compiling world history. So when domestic scholars asked for the change for world history system in the 1980s, Mr. Wu Yujin put forward that the holistic conception of world history in China is gradually developing. From Mr. Wu's point of view, world history is a kind of mystery and hazy thing, and very likely become true in reality. Here's three points of analysis addressing Mr. Wu Yujin's thinking about Chinese world history. 
1). Among historical disciplines, the World History Discipline has a certain limited significance. The main learning aim of the World History Discipline is to investigate the process of world development since ancient times, to explore the process how human beings gradually developed from an original, wild, scattered and closed environment to an advanced, civilized, collective, open, interrelated and overall world history. Explore the above content with a stage of country history, area history and subject history. At the same time, understand the definition of world history in a correct way and clearly know that world history is not a simple addition of the history of all countries, nations and areas.

After we correctly understand the definition of world history, we should correctly understand the relationship between Chinese history and world history: Chinese history and world history are two different subjects and there are no parallel and coordinate relations between them. Because Chinese history belongs to national history, national history has no coordinating relation with world history. So Chinese history could appose itself with French history, English history and American History, but not world history. As mentioned quite a few times before, world history is not a simple addition and its main research direction is also not a simple addition of history of all countries.

2). In terms of research direction of world history, the idea that regarding some nation or area as the center of world is very one-sided. In order to obtain an objective and comprehensive study about world history, the national parochialism and the local protectionism should be broke. During the process of world history research, Mr. Wu Yujin found out that not only western scholars get used to regarding their own country as the center to study world history, so do Chinese scholars. Domestic scholars should clearly know that on the geographical position, China is just a country in the east. For instance, after our ancestors saw the position of China is just on the east corner from the world map which was brought by Matteo Ricci, they were quite furious. Because they always considered themselves as the center of the world. Though now we think this kind of idea is quite absurd and ridiculous, numerous people still have this kind of idea. A classic example is that when we see some westerners think their countries are the centers of the world, many people can't help opposing and think that our country is the center of the world since some historical period to enhance the international status of our country. This is quite similar with nostalgia which was put forward by Benedetti Croce. When we carry out a study of world history, this shortcoming must be avoided to analyze in an objective and precise way.

3). During the process of world history research, the unity of the objective law cannot be regarded as the most important content. We can ignore the exactness of the unity of this objective law in the category of philosophy first, but we can precisely say that to explain the unity of this objective law is definitely not the main direction of world history. We did not reject unity systems that seeks variety, such as the Toynbee civilization system, the Soviet System of world history etc..Speaking of requiring the unity of the objective law, the forms are really diverse. We just object the research which aims for supplement of unity. So far, some points of views from the western world history in the 18th century still have important influence on example systems above and they think that world history is a addition of various countries and civilizations. Now, people summarize common characteristics of the law of historical development and blend them in the content of world history. This ideology has a great impact on world history scholars and we should try our best to avoid it during the study.

4). World history is an integrated whole. So we should regard the process of history developing into world history as the uppermost content when we study it. Though other research areas of history can provide some requirements, only the study of world history can make the exploration of this theme done. We've mentioned from the previous statement that world history is an outcome of historical development. Under the influence of Mr. Wu Yujin's holistic world outlook, the main task becomes the investigation to the process that history develops into world history. This is the first time to notice this issue. 


\section{Conclusion}

Nowadays, in the area of the historical research, numerous scholars at home and abroad have accepted Mr. Wu Yujin's theory of macrocosm, and its status in the international historical research is increasingly important. All of this shows that the unfinished wish of world history research before Mr. Wu Yujin's death is gradually realizing. As the study of world history includes contents of a lot of aspects and is very large and complex, the study of world history in China is still in a initial stage now. If we want to render it mature step by step, young and middle-aged scholars need to inherit $\mathrm{Mr}$. $\mathrm{Wu}$ Yujin's will to take up the heavy responsibility, promoting the development of studies on the conception of world history in our country. We believe that under the joint efforts of many historians, significant achievements on world history research will be accomplished. However, we should never forget the pioneering achievements about world history accomplished by the earliest scholars in China, such as Mr. Wu Yujin. This article specially stated in line with Mr. Wu Yujin's research on world history. It is not only a way of doing my bit for the world history research, but also presenting my eternal recalling and respect to Mr. Wu Yujin.

\section{References}

[1] Qi Shirong: Mr. Wu Yujin and the Establishment of the World History Discipline in China. Journal of Wuhan University (Humanity Science),2013,06:20-23.

[2]An Changchun: Mr. Wu Yujin and the Establishment of the World History Discipline in China. Journal of Wuhan University (Humanity Science),2013,06:26-29.

[3]Liu Jinghua: Mr Wu Yujin's Discussion toward the Academic Origin of the Holistic Conception of World History. Journal of Wuhan University (Humanity Science),2013,06:32-40.

[4] Chen Zhiqiang: Mr Wu Yujin's Contribution to Macro-theory of World History. Studies of Modern World History,2013,00:97-101+331.

[5] Yu Jinyao: The Disciplinary Orientation between 'History of the world'and World History. Journal of Historical Science,2009,10:81-89.

[6] Feng Tianyu, Wu Yu, Guo Qiyong etc: A Study on Mr Wu Yujin’ s Feudalism and His Historical Contribution.Journal of Wuhan University (Humanity Science),2013,04:5-25.

[7] Meng Guanglin: 'General view’ of the study of world history-Mr Wu Yujin' s Academic State.Collected Papers of History Studies,2013,04:3-10.

[8] Zhao Wenliang: The Compilation of the Holistic Historical View and Chinese World History. World History,2011,06:105-118. 